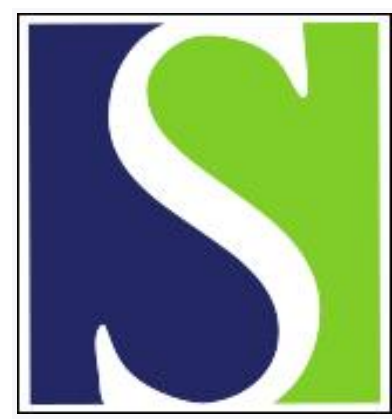

Scand J Work Environ Health 1986;12(6):619-626

https://doi.org/10.5271/sjweh.2093

Issue date: Dec 1986

Smoking among Finnish pulp and paper workers--evaluation of its confounding effect on lung cancer and coronary heart disease rates.

by Jappinen $\mathrm{P}$, Tola $\mathrm{S}$

This article in PubMed: www.ncbi.nlm.nih.gov/pubmed/3823812

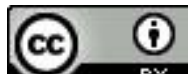




\title{
Smoking among Finnish pulp and paper workers - Evaluation of its confounding effect on lung cancer and coronary heart disease rates
}

\author{
by Paavo Jäppinen, $M D,{ }^{1}$ Sakari Tola, $M D^{2}$
}

\begin{abstract}
JÄPPINEN P, TOLA S. Smoking among Finnish pulp and paper workers - Evaluation of its confounding effect on lung cancer and coronary heart disease rates. Scand $J$ Work Environ Health 12 (1986) 619626. The possible confounding caused by smoking was studied in connection with a mortality and cancer incidence study of 3520 workers in the pulp and paper industry. A group of 1290 sawmill workers was used for comparison in addition to the expected numbers based on national statistics. A total of 801 questionnaires was sent to a representative sample of the workers, 537 to people still alive and 264 to the next-ofkin of decedents. The reply percentage was 86.6 for the former and 80.9 for the latter. The prevalence of smoking was determined for 1956 and 1981. The proportions of moderate and heavy smokers were assessed for 1981, and smoking indices were calculated for each occupational group. The estimated rate ratios for lung cancer in relation to smoking categories and the corresponding smoking-adjusted standardized incidence ratios were calculated for 1981, and they were compared with the observed standardized incidence ratios for lung cancer. The smoking habits could not explain the observed excess of lung cancer, nor the increased mortality from coronary heart disease found among the pulp and paper workers. Postal questionnaires may be a feasible tool for assessing smoking habits in retrospective cohort studies.
\end{abstract}

Key terms: estimated rate ratios, questionnaire, prevalence, smoking-adjusted standardized incidence ratios, smoking index.

Ever since the early work of Doll \& Hill (4) it has been obvious that smoking has a profound effect on both cancer incidence and mortality. Cancers of the lungs, larynx, esophagus, and bladder, as well as coronary heart disease, bronchitis, and emphysema, are some of the diseases associated with smoking. The role of smoking as a confounding factor in epidemiologic studies has been evaluated by several authors, and mathematical formulas for assessing its effect on lung cancer have been presented by Axelson (2) and applied by Asp (1). A prerequisite for the use of such formulas is that the smoking habits of the populations in question be known in sufficient detail (17), but information on smoking habits is often difficult to obtain. Furthermore, a point estimate of the prevalence of smoking is usually not sufficient, since smoking patterns change, as Hammond \& Garfinkel (7), Rimpelä (15), and others have pointed out. As subtler and subtler effects of occupational exposure are being studied by epidemiologic methods, it becomes increasingly important to control known confounding factors.

Recently, a retrospective mortality and cancer incidence study was made on Finnish pulp and paper workers (9, Jäppinen et al, unpublished), and the smoking habits of the population were determined by

1 Enso-Gutzeit Oy, Occupational Health Centre, Imatra, Finland.

2 Institute of Occupational Health, Department of Epidemiology and Biostatistics, Topeliuksenkatu 41 a A, SF-00250 Helsinki, Finland.

Reprint requests to: Dr P Jäppinen, Enso-Gutzeit Oy, Occupational Health Centre, SF-55800 Imatra, Finland. questionnaire. The results of this questionnaire are reported in the present communication with special emphasis on the confounding effect of smoking on the observed risks of lung cancer and coronary heart disease.

\section{Subjects and methods}

The cohort consisted of 3520 workers in three pulp and paper mills located in southeastern Finland. One mill, now closed, used the acidic or sulfite pulping method, and the other two, still in operation, used the alkaline or sulfate pulping method. The workers were divided into groups according to their work environment as follows: sulfite mill, sulfate mill, paper mill, board mill, maintenance department, and power plant (table 1). A cohort of 1290 sawmill workers was used for internal comparison. All the workers in the two cohorts had been working in their respective areas continuously for at least one year between 1 January 1945 and 31 December 1961. The basic source of the data was the company employee files. Personal data, including follow-up to death before 31 December 1981, were confirmed in the National Population Register or in the local population registers. The cause of death was obtained from the Central Statistical Office of Finland. The incidence of cancer was monitored until 31 December 1980 with the use of data from the Finnish Cancer Register. All members of the cohorts were identified. The follow-up was complete for all but 16 persons, all of whom had emigrated from Finland to 
Table 1. Number of workers and questionnaires by sex.

\begin{tabular}{lrrrrrrr}
\hline \multirow{2}{*}{ Cohort } & \multicolumn{3}{c}{ Number of workers } & & \multicolumn{3}{c}{ Number of questionnaires } \\
\cline { 2 - 4 } & Males & Females & Total & & Males & Females & Total \\
\hline Pulp and paper & 2696 & 824 & 3520 & & 473 & 184 & 657 \\
Sulfite mill & 212 & 84 & 296 & 68 & 29 & 97 \\
Sulfate mill & 501 & 226 & 727 & 67 & 48 & 115 \\
Paper mill & 179 & 213 & 392 & 47 & 61 & 108 \\
Board mill & 648 & 218 & 866 & 85 & 31 & 116 \\
Maintenance department & 776 & 54 & 830 & 109 & 87 & 117 \\
Power plant & 380 & 29 & 409 & 97 & 7 & 104 \\
Sawmill & 518 & 772 & 1290 & & 87 & 57 & 144 \\
\hline
\end{tabular}

places with inadequate registers. At the end of 1981, 3289 of the workers were alive and 1505 were dead.

The observed death and cancer incidence rates were compared with the corresponding age-specific rates for the Finnish population (in the mortality study) or the population of the province of Kymi (in the cancer incidence study). In the mortality study, an excess of deaths from diseases of the circulatory system and, especially, from ischemic heart disease was found among the men in the pulp and paper cohort, the excess originating from the sulfite mill, sulfate mill, paper mill, maintenance department, and power plant groups (9). In the cancer incidence study, an excess of lung cancer was observed for men in the pulp and paper cohort, the excess originating from the paper mill, board mill, and maintenance department groups (Jäppinen et al, unpublished).

Both lung cancer and coronary heart disease are known to be associated with smoking. Therefore we considered it relevant to determine the extent to which the observed effects could be explained by confounding by smoking. Smoking habits were surveyed by means of self-administered questionnaires sent to statistically representative samples of each group of the paper and pulp cohort and the sawmill cohort (table 1). The workers in each group were listed in alphabetical order, without separation for gender or vital status, and the sample was selected with the use of random numbers. More questionnaires were mailed than the least statistically representative number would have presumed (3) because the response rate could not be predicted.

Two slightly different questionnaires were used, one for those alive and the other for the next-of-kin of the deceased. The former consisted of the following questions: 1 . Have you ever worked in a dusty environment or in an environment causing respiratory irritation? If your answer is yes, when and where? 2. Do you smoke at present? 3. Have you smoked previously, but have now given it up? 4. How many years have you smoked altogether? (to be answered also by those who have given up smoking) 5 . For those who have given up smoking: In what year did you stop? 6. What is (was) your average consumption of tobacco products? 7. Did you smoke in 1956 ? The same information was sought with the questionnaire sent to the next-of-kin of the decedents, but the questions were slightly modi- fied. A reminder was sent to nonrespondents three weeks after the original mailing and again two weeks later, whenever necessary.

The year 1956 was chosen as a reference point in the questionnaire because it was well within the study period for mortality and cancer incidence, and information was available on the prevalence of cigarette smoking in the general Finnish population during that year (11). Moreover, in 1956 there was a general strike in Finland, clearly remembered by most people living at the time. The specific consumption of tobacco products in 1956 was not requested because the answers would most likely have been inaccurate, and a toodetailed questionnaire tends to lower response rate.

The smoking habits of the persons in the 15- to 69-year age range in 1956 were compared to those of persons in the corresponding age range in 1981 for information on possible changes. In addition the consumption of tobacco products among those smoking in 1981 was determined. Vital status in 1981 was related to smoking status in 1956. Furthermore, the proportion of smokers in the 15- to 69-year age range in 1956 who were still smokers in 1981 was determined. For the analysis of the risk of contracting lung cancer as a function of smoking, a smoking index $(12,14)$ was determined for each group on the basis of the smoking data for 1981 . The index $(I)$ was calculated according to the formula:

$$
I=1 \times N+5 \times M+15 \times H,
$$

where $N=$ percentage of nonsmokers (including exsmokers), $M=$ percentage of moderate smokers $(<15$ cigarettes per day, including pipe and cigar smokers), $H=$ percentage of heavy smokers (at least 15 cigarettes per day); and 1, 5 and $15=$ presumed relative risk of lung cancer among nonsmokers, moderate smokers, and heavy smokers, respectively.

The correlation between the standardized incidence ratio (SIR) for lung cancer and the prevalence of smoking in each group, in both 1956 and 1981, was analyzed, as was the correlation between the standardized mortality ratio (SMR) for ischemic heart disease and the prevalence of smoking in 1956. Finally, the potential confounding effect of smoking habits on the rate ratios of lung cancer in each occupational group was analyzed according to the method presented by Axel- 
son (2), although different presumed relative risks were used for the three smoking categories. The sawmill workers, the workers in the entire pulp and paper industry, or the general Finnish population (Piha and co-workers, unpublished) were used as reference populations.

The estimated rate ratios were calculated as follows: If $I=$ total incidence, $I_{0}=$ incidence among nonsmokers (including exsmokers), $I_{s}=$ incidence caused by smoking, $P_{s}=$ proportion of moderate smokers or heavy smokers in the population, and $R=$ assumed effect of smoking expressed as a rate ratio, then:

$$
I=I_{s} P_{s}+I_{0}\left(1-P_{s}\right),
$$

$I_{s} P_{s}$ can be expressed as $R I_{0} P_{s}$. With the two smoking categories (moderate and heavy smokers), the model is expanded to:

$$
I=R_{1} I_{0} P_{s 1}+R_{2} I_{0} P_{s 2}+I_{0}\left(1-P_{s 1}-P_{s 2}\right) .
$$

$I_{0}$ of the reference population is divided by the $I_{0}$ of each group.

The smoking-adjusted SIR values for lung cancer among the men in the different occupational groups were computed by dividing the observed SIR values by the corresponding estimated rate ratios.

\section{Results}

The response rates for the questionnaires sent to the different occupational groups ranged from 82.3 to $94.2 \%$ for persons still alive and from 58.2 to $96.7 \%$

Table 2. Number of replies to the questionnaires and the corresponding response rates in percentage (as number of total

\begin{tabular}{|c|c|c|c|c|c|c|}
\hline \multirow{3}{*}{ Cohort } & \multicolumn{6}{|c|}{ Vital status } \\
\hline & \multicolumn{2}{|c|}{ Alive } & \multicolumn{2}{|c|}{ Dead } & \multicolumn{2}{|c|}{ Total } \\
\hline & $\begin{array}{l}\text { Number of } \\
\text { replies }\end{array}$ & $\%$ & $\begin{array}{l}\text { Number of } \\
\text { replies }\end{array}$ & $\%$ & $\begin{array}{l}\text { Number of } \\
\text { replies }\end{array}$ & $\%$ \\
\hline Pulp and paper & 388 & 86.6 & 169 & 80.9 & 557 & 84.8 \\
\hline $\begin{array}{l}\text { Sulfite mill } \\
\text { Sulfate mill } \\
\text { Paper mill } \\
\text { Board mill } \\
\text { Maintenance department } \\
\text { Power plant }\end{array}$ & $\begin{array}{l}49 \\
68 \\
61 \\
71 \\
74 \\
65\end{array}$ & $\begin{array}{l}94.2 \\
91.9 \\
82.4 \\
86.6 \\
85.1 \\
82.3\end{array}$ & $\begin{array}{l}34 \\
34 \\
22 \\
28 \\
29 \\
22\end{array}$ & $\begin{array}{l}75.6 \\
82.9 \\
64.7 \\
82.4 \\
96.7 \\
88.0\end{array}$ & $\begin{array}{r}83 \\
102 \\
83 \\
99 \\
103 \\
87\end{array}$ & $\begin{array}{l}85.6 \\
88.7 \\
76.9 \\
85.3 \\
88.0 \\
83.7\end{array}$ \\
\hline Sawmill & 75 & 84.3 & 32 & 58.2 & 107 & 74.3 \\
\hline
\end{tabular}
replies/number of questionnaires sent) by vital status on 31 December 1981 .

Table 3. Prevalence of 15- to 69-year-old smokers in 1956 and 1981 by sex and the change between the two years. (SE $=$ standard

\begin{tabular}{|c|c|c|c|c|c|}
\hline \multirow{3}{*}{ Cohort } & \multicolumn{4}{|c|}{ Prevalence of smoking } & \multirow{3}{*}{ Change $(\%)$} \\
\hline & \multicolumn{2}{|c|}{1956} & \multicolumn{2}{|c|}{1981} & \\
\hline & $\%$ & $\mathrm{SE}$ & $\%$ & $\mathrm{SE}$ & \\
\hline \multicolumn{6}{|c|}{ Pulp and paper } \\
\hline $\begin{array}{l}\text { Males } \\
\text { Females }\end{array}$ & $\begin{array}{r}55.1 \\
6.9\end{array}$ & $\begin{array}{l}2.4 \\
1.9\end{array}$ & $\begin{array}{l}37.3 \\
15.0\end{array}$ & $\begin{array}{l}3.3 \\
3.7\end{array}$ & $\begin{array}{r}-17.8 \\
+\quad 8.1\end{array}$ \\
\hline \multicolumn{6}{|l|}{ Sulfite mill } \\
\hline $\begin{array}{l}\text { Males } \\
\text { Females }\end{array}$ & $\begin{array}{r}55.2 \\
3.4\end{array}$ & $\begin{array}{l}6.5 \\
3.4\end{array}$ & $\begin{array}{r}36.8 \\
0.0\end{array}$ & 11.1 & $\begin{array}{l}-18.4 \\
-\quad 3.4\end{array}$ \\
\hline \multicolumn{6}{|l|}{ Sulfate mill } \\
\hline $\begin{array}{l}\text { Males } \\
\text { Females }\end{array}$ & $\begin{array}{r}80.0 \\
6.3\end{array}$ & $\begin{array}{l}5.1 \\
3.5\end{array}$ & $\begin{array}{l}30.8 \\
17.9\end{array}$ & $\begin{array}{l}9.1 \\
7.7\end{array}$ & $\begin{array}{l}-49.2 \\
+11.6\end{array}$ \\
\hline \multicolumn{6}{|l|}{ Paper mill } \\
\hline $\begin{array}{l}\text { Males } \\
\text { Females }\end{array}$ & $\begin{array}{r}61.9 \\
5.3\end{array}$ & $\begin{array}{l}7.5 \\
3.0\end{array}$ & $\begin{array}{l}52.6 \\
24.0\end{array}$ & $\begin{array}{r}11.5 \\
8.9\end{array}$ & $\begin{array}{r}-9.3 \\
+18.9\end{array}$ \\
\hline \multicolumn{6}{|l|}{ Board mill } \\
\hline $\begin{array}{l}\text { Males } \\
\text { Females }\end{array}$ & $\begin{array}{l}54.2 \\
11.5\end{array}$ & $\begin{array}{l}5.9 \\
6.3\end{array}$ & $\begin{array}{r}38.1 \\
8.7\end{array}$ & $\begin{array}{l}7.7 \\
6.0\end{array}$ & $\begin{array}{l}-16.1 \\
-\quad 2.8\end{array}$ \\
\hline \multicolumn{6}{|c|}{ Maintenance department } \\
\hline $\begin{array}{l}\text { Males } \\
\text { Females }\end{array}$ & $\begin{array}{l}46.8 \\
10.0\end{array}$ & $\begin{array}{l}5.1 \\
9.5\end{array}$ & $\begin{array}{l}27.9 \\
20.0\end{array}$ & $\begin{array}{r}6.0 \\
17.9\end{array}$ & $\begin{array}{l}-18.9 \\
+10.0\end{array}$ \\
\hline \multicolumn{6}{|l|}{ Power plant } \\
\hline $\begin{array}{l}\text { Males } \\
\text { Females }\end{array}$ & $\begin{array}{l}50.5 \\
20.0\end{array}$ & $\begin{array}{r}5.2 \\
17.9\end{array}$ & $\begin{array}{l}45.3 \\
16.7\end{array}$ & $\begin{array}{r}7.0 \\
15.2\end{array}$ & $\begin{array}{l}-5.2 \\
-3.3\end{array}$ \\
\hline \multicolumn{6}{|l|}{ Sawmill } \\
\hline $\begin{array}{l}\text { Males } \\
\text { Females }\end{array}$ & $\begin{array}{r}51.3 \\
9.1\end{array}$ & $\begin{array}{l}5.6 \\
3.9\end{array}$ & $\begin{array}{r}51.4 \\
8.3\end{array}$ & $\begin{array}{l}8.7 \\
6.0\end{array}$ & $\begin{array}{l}+0.1 \\
-0.8\end{array}$ \\
\hline
\end{tabular}
error of the proportion) 
Table 4. Prevalence of nonsmokers (including exsmokers), moderate smokers $(<15$ cigarettes/d, including pipe and cigar smokers), and heavy smokers ( $\geq 15$ cigarettes/d) among the men 15 to 69 years of age on 31 December 1981 and the calculated smoking index for the different occupational groups of the paper and pulp cohort and for the sawmill cohort. (SE = standard error of the proportion)

\begin{tabular}{|c|c|c|c|c|c|c|c|}
\hline \multirow[t]{2}{*}{ Cohort } & \multicolumn{2}{|c|}{ Nonsmokers } & \multicolumn{2}{|c|}{$\begin{array}{l}\text { Moderate } \\
\text { smokers }\end{array}$} & \multicolumn{2}{|c|}{$\begin{array}{c}\text { Heavy } \\
\text { smokers }\end{array}$} & \multirow{2}{*}{$\begin{array}{c}\text { Smoking } \\
\text { index }\end{array}$} \\
\hline & $\%$ & SE & $\%$ & SE & $\%$ & SE & \\
\hline Pulp and paper & 62.7 & 3.3 & 11.8 & 2.2 & 25.5 & 3.0 & 504 \\
\hline $\begin{array}{l}\text { Sulfite mill } \\
\text { Sulfate mill } \\
\text { Paper mill } \\
\text { Board mill } \\
\text { Maintenance department } \\
\text { Power plant }\end{array}$ & $\begin{array}{l}63.2 \\
69.2 \\
47.4 \\
61.9 \\
72.1 \\
54.7\end{array}$ & $\begin{array}{r}11.1 \\
9.1 \\
11.5 \\
7.7 \\
6.0 \\
7.0\end{array}$ & $\begin{array}{r}10.5 \\
3.8 \\
5.2 \\
19.0 \\
9.8 \\
15.1\end{array}$ & $\begin{array}{l}7.0 \\
3.7 \\
5.1 \\
6.2 \\
4.0 \\
5.0\end{array}$ & $\begin{array}{l}26.3 \\
26.9 \\
47.4 \\
19.0 \\
18.1 \\
30.2\end{array}$ & $\begin{array}{r}10.1 \\
8.7 \\
11.5 \\
6.2 \\
5.1 \\
6.4\end{array}$ & $\begin{array}{l}510 \\
492 \\
784 \\
442 \\
393 \\
583\end{array}$ \\
\hline Sawmill & 48.5 & 8.7 & 28.6 & 7.9 & 22.9 & 7.3 & 535 \\
\hline
\end{tabular}

Table 5. Prevalence of smokers in the 15- to 69-year age range in 1956 by vital status on 31 December 1981. (SE = standard error of the proportion)

\begin{tabular}{|c|c|c|c|c|}
\hline \multirow{2}{*}{ Cohort } & \multirow{2}{*}{$\begin{array}{l}\text { Number of } \\
\text { valid replies }\end{array}$} & \multirow{2}{*}{$\begin{array}{l}\text { Number of } \\
\text { smokers }\end{array}$} & \multicolumn{2}{|c|}{$\begin{array}{l}\text { Proportion } \\
\text { of smokers }\end{array}$} \\
\hline & & & $\%$ & SE \\
\hline \multicolumn{5}{|c|}{ Pulp and paper } \\
\hline $\begin{array}{l}\text { Alive } \\
\text { Dead }\end{array}$ & $\begin{array}{l}370 \\
159\end{array}$ & $\begin{array}{l}150 \\
105\end{array}$ & $\begin{array}{l}40.5 \\
66.0\end{array}$ & $\begin{array}{l}2.6 \\
3.8\end{array}$ \\
\hline \multicolumn{5}{|c|}{ Sulfite mill } \\
\hline $\begin{array}{l}\text { Alive } \\
\text { Dead }\end{array}$ & $\begin{array}{l}48 \\
30\end{array}$ & $\begin{array}{l}16 \\
21\end{array}$ & $\begin{array}{l}33.3 \\
70.0\end{array}$ & $\begin{array}{l}6.8 \\
8.4\end{array}$ \\
\hline \multicolumn{5}{|c|}{ Sulfate mill } \\
\hline $\begin{array}{l}\text { Alive } \\
\text { Dead }\end{array}$ & $\begin{array}{l}68 \\
34\end{array}$ & $\begin{array}{l}24 \\
25\end{array}$ & $\begin{array}{l}35.3 \\
73.5\end{array}$ & $\begin{array}{l}5.8 \\
7.6\end{array}$ \\
\hline \multicolumn{5}{|c|}{ Paper mill } \\
\hline $\begin{array}{l}\text { Alive } \\
\text { Dead }\end{array}$ & $\begin{array}{l}58 \\
20\end{array}$ & $\begin{array}{l}18 \\
11\end{array}$ & $\begin{array}{l}31.0 \\
55.0\end{array}$ & $\begin{array}{r}6.1 \\
11.1\end{array}$ \\
\hline \multicolumn{5}{|c|}{ Board mill } \\
\hline $\begin{array}{l}\text { Alive } \\
\text { Dead }\end{array}$ & $\begin{array}{l}65 \\
27\end{array}$ & $\begin{array}{l}27 \\
15\end{array}$ & $\begin{array}{l}41.5 \\
55.6\end{array}$ & $\begin{array}{l}6.1 \\
9.6\end{array}$ \\
\hline \multicolumn{5}{|c|}{$\begin{array}{l}\text { Maintenance } \\
\text { department }\end{array}$} \\
\hline $\begin{array}{l}\text { Alive } \\
\text { Dead }\end{array}$ & $\begin{array}{l}69 \\
27\end{array}$ & $\begin{array}{l}29 \\
18\end{array}$ & $\begin{array}{l}42.0 \\
66.7\end{array}$ & $\begin{array}{l}5.9 \\
9.1\end{array}$ \\
\hline \multicolumn{5}{|c|}{ Power plant } \\
\hline $\begin{array}{l}\text { Alive } \\
\text { Dead }\end{array}$ & $\begin{array}{l}62 \\
21\end{array}$ & $\begin{array}{l}36 \\
15\end{array}$ & $\begin{array}{l}58.1 \\
71.4\end{array}$ & $\begin{array}{l}6.3 \\
9.9\end{array}$ \\
\hline \multicolumn{5}{|l|}{ Sawmill } \\
\hline $\begin{array}{l}\text { Alive } \\
\text { Dead }\end{array}$ & $\begin{array}{l}74 \\
30\end{array}$ & $\begin{array}{l}33 \\
13\end{array}$ & $\begin{array}{l}44.6 \\
43.3\end{array}$ & $\begin{array}{l}5.8 \\
9.0\end{array}$ \\
\hline
\end{tabular}

for the next-of-kin of the decedents (table 2). Among those still alive, the first request produced $56-68 \%$ of the replies in the different groups, the second $16-27 \%$, and the third $1-6 \%$. For the next-of-kin, the first request yielded $31-63 \%$, the second $12-$ $33 \%$, and the third $3-7 \%$ of the replies, respectively.

Smoking frequencies in the 15 - to 69 -year age range had changed substantially between 1956 and 1981 (table 3). The prevalence ranged from 27.9 to $52.6 \%$ for the men alive in the different groups on 31 December 1981 , and from 0 to $24 \%$ for the women. In 1956 between 46.8 and $80.0 \%$ of the men and between 3.4 and $20.0 \%$ of the women in the different groups were smokers. In the total cohort smoking had decreased
Table 6. Estimated rate ratios of lung cancer among the men in relation to the percentages of nonsmokers (including exsmokers) $(R=1)$, moderate smokers $(R=5)$, and heavy smokers $(R=15)$ with the general Finnish male population (Piha and co-workers, unpublished) (A), the men employed in the sawmill (B), and the men employed in the entire pulp and paper industry $(C)$ as reference. The smoking data for the men (15 to 69-years of age), in the paper and pulp cohort are from 3 December 1981. ( $R=$ presumed relative risk of lung cancer)

\begin{tabular}{lccc}
\hline \multirow{2}{*}{ Cohort } & \multicolumn{3}{c}{ Estimated rate ratio } \\
\cline { 2 - 4 } & $\mathrm{A}$ & $\mathrm{B}$ & $\mathrm{C}$ \\
\hline Pulp and paper & 1.06 & 0.94 & 1.00 \\
Sulfite mill & 1.08 & 0.95 & 1.01 \\
Sulfate mill & 1.04 & 0.92 & 0.97 \\
Paper mill & 1.65 & 1.47 & 1.56 \\
Board mill & 0.93 & 0.83 & 0.88 \\
Maintenance department & 0.83 & 0.73 & 0.78 \\
Power plant & 1.23 & 1.09 & 1.16 \\
Sawmill & 1.13 & 1.00 & 1.06 \\
\hline
\end{tabular}

by $17.8 \%$ among the men and increased by $8.1 \%$ among the women. Among the sawmill workers, there was a minimal increase $(0.1 \%)$ in the prevalence of smoking from 1956 to 1981 for the men and a decrease of $0.8 \%$ for the women.

The proportion of male smokers 15 to 69 years of age in 1956 and still smokers in 1981 ranged from 23.1 (board mill) to 64.7 (sulfite mill) $\%$ in the different groups. The proportion of men in the same age range who were nonsmokers in 1956 but smokers in 1981 ranged from 15.2 (maintenance department) to 47.1 (board mill) $\%$ in the different groups. For the sawmill reference cohort the corresponding figure was $8.3 \%$.

The proportions of moderate and heavy smokers 15 to 69 years of age in each occupational group in 1981 are shown in table 4 . The smoking indices for these groups varied between 393 and 784 . The smoking index for the general Finnish male population was 474 in 1981 , based on the unpublished data of Piha and coworkers.

In each occupational group, there were more smokers in 1956 among those who had died by 1981 than among those alive (table 5). The vital status for the 

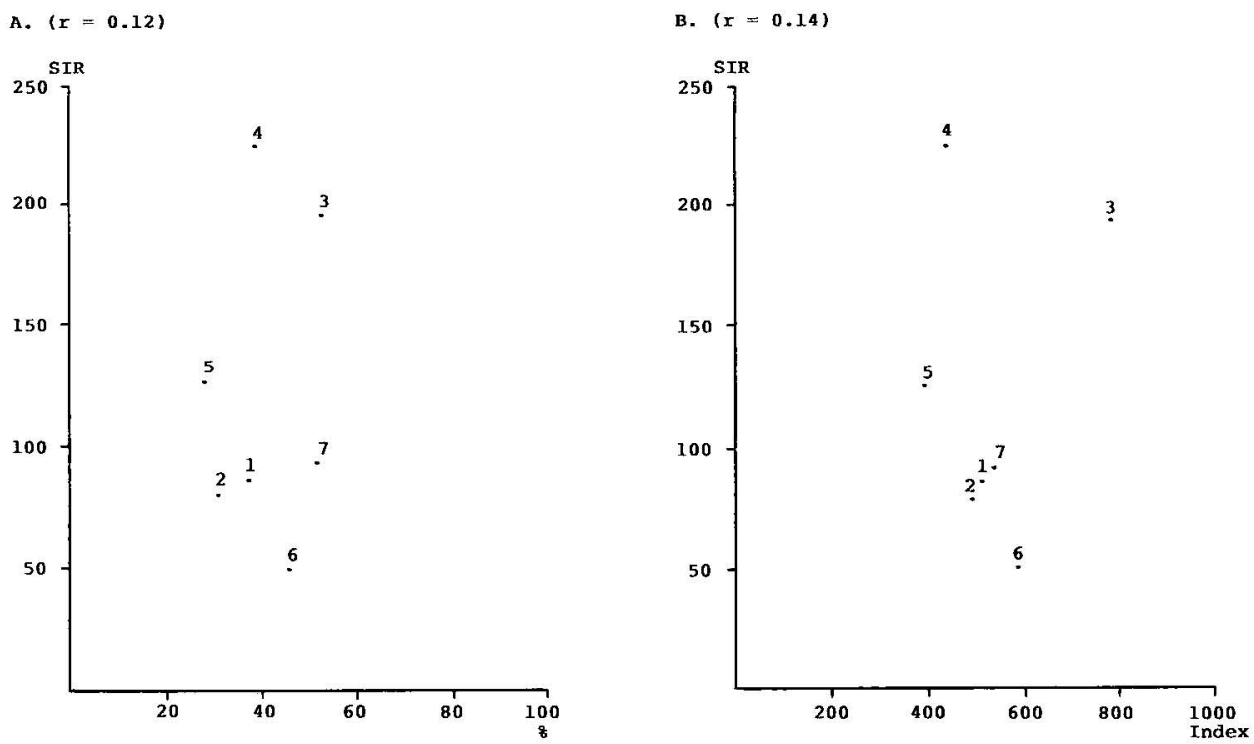

Figure 1. Correlation between the standardized incidence ratio of lung cancer among the men and the prevalence of smoking on 31 December 1981 (A) or the corresponding smoking index (B) assessed for the different occupational groups of the pulp and paper cohort and for the sawmill cohort. $(1=$ sulfite mill, $2=$ sulfate mill, $3=$ paper mill, $4=$ board mill, $5=$ maintenance department, $6=$ power plant, $7=$ sawmill, and $r=$ correlation coefficient)

A. $(r=-0.06)$

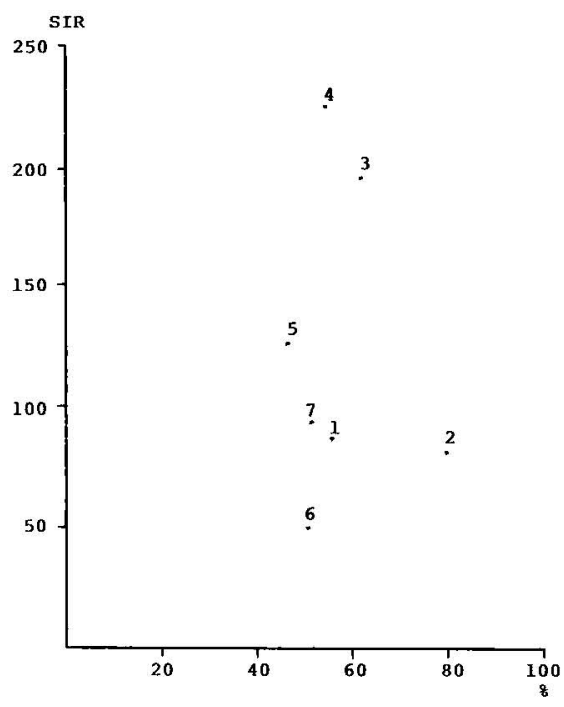

B. $(r=0.34)$

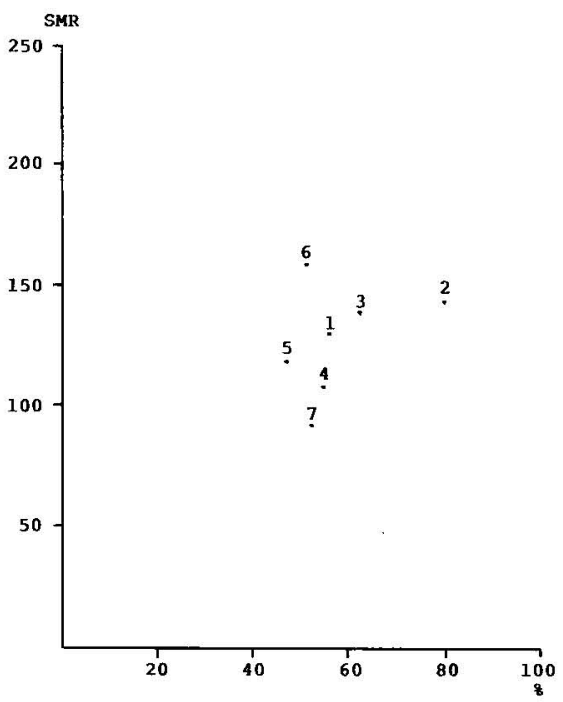

Figure 2. Correlation between the standardized incidence ratio of lung cancer among the men (A) and mortality from ischemic heart disease among the men (B) and the prevalence of smoking in 1956 assessed for the different occupational groups of the pulp and paper cohort and for the sawmill cohort. $(1=$ sulfite mill, $2=$ sulfate mill, $3=$ paper mill, $4=$ board mill, $5=$ maintenance department, $6=$ power plant, $7=$ sawmill, and $r=$ correlation coefficient)

sawmill workers did not correlate with the smoking habits in 1956, but the response rate of the next-ofkin of the dead sawmill workers was rather low.

The men showed a weak correlation between the SIR for lung cancer and both the prevalence of smoking in 1981 and the smoking index. The correlation coefficients were 0.12 and 0.14 (figure 1), respectively. In addition the correlation between the SIR for lung cancer or the SMR for ischemic heart disease among men on one hand and the prevalence of smoking in 1956 on the other was rather weak (figure 2).

The estimated rate ratios for lung cancer among the men in relation to the percentages of nonsmokers, moderate smokers, and heavy smokers (table 6) ranged from 0.83 to 1.65 for the different groups when the general Finnish male population was used as reference. The smoking data for the general population were from the year 1981 (Piha and co-workers, unpub- 
Table 7. Smoking-adjusted standardized incidence ratio (SIR) values and their $95 \%$ confidence intervals (95\% CI) for lung cancer among the men in the different groups with the general Finnish male population (Piha and co-workers, unpublished) (A), the men employed in the sawmill (B), and the men employed in the entire pulp and paper industry (C) as reference. The smoking data for the men (15- to 69-years of age) in the paper and pulp cohort are from 31 December 1981.

\begin{tabular}{|c|c|c|c|c|c|}
\hline \multirow[t]{2}{*}{ Cohort } & \multirow{2}{*}{$\begin{array}{l}\text { Observed SIR } \\
\text { for lung cancer } \\
\text { among the men }\end{array}$} & \multirow[t]{2}{*}{$95 \% \mathrm{Cl}$} & \multicolumn{3}{|c|}{$\begin{array}{l}\text { Smoking-adjusted SiR for } \\
\text { lung cancer among the men }\end{array}$} \\
\hline & & & A & B & $\mathrm{C}$ \\
\hline Pulp and paper & 125 & $98-156$ & 118 & 133 & 125 \\
\hline $\begin{array}{l}\text { Sulfite mill } \\
\text { Sulfate mill } \\
\text { Paper mill } \\
\text { Board mill } \\
\text { Maintenance department } \\
\text { Power plant }\end{array}$ & $\begin{array}{r}88 \\
81 \\
195 \\
226 \\
127 \\
50\end{array}$ & $\begin{array}{r}38-174 \\
43-139 \\
97-349 \\
161-308 \\
92-171 \\
16-117\end{array}$ & $\begin{array}{r}81 \\
78 \\
118 \\
243 \\
153 \\
41\end{array}$ & $\begin{array}{r}93 \\
88 \\
133 \\
272 \\
174 \\
46\end{array}$ & $\begin{array}{r}87 \\
84 \\
125 \\
257 \\
163 \\
43\end{array}$ \\
\hline Sawmill & 94 & $61-140$ & 83 & 94 & 89 \\
\hline
\end{tabular}

lished). When male workers from the sawmill were used for reference, the estimated rate ratios varied from 0.73 to 1.47 . With the male workers in the entire pulp and paper industry as reference, the corresponding ratios were from 0.78 to 1.56 . For the men in the pulp and paper cohort, the estimated smoking-adjusted rate ratio for lung cancer was 1.06 with the general Finnish male population as reference and 0.94 with the male sawmill workers as reference.

The observed SIR values for lung cancer among the men and the corresponding smoking-adjusted SIR values for each occupational group are shown in table 7, the general Finnish male population or male sawmill workers or all male pulp and paper workers being used as reference.

The smoking-adjusted SIR for lung cancer among the men was higher than the nonadjusted value for the board mill group ( 243 or 272 versus 226 ) and the maintenance department group (153 or 174 versus 127) when either the general male population or the males employed in the sawmill were used as reference. Thus smoking could not explain the excess of lung cancer among the men in these occupational groups. On the contrary, the unadjusted rate ratios appeared to be underestimates. The smoking-adjusted SIR for lung cancer among the men in the entire pulp and paper cohort was somewhat lower than the nonadjusted value (118 versus 125 ) when the general male population was used as reference and higher (133 versus 125) when male sawmill workers were used as reference. For the male paper mill workers the corresponding figures were 118 and 133 versus 195 . These values indicate a slightly increased risk of lung cancer even after adjustment for smoking in this group.

The high prevalence of smoking among male sulfate mill workers in $1956(80 \%)$ could partly explain the excess of coronary deaths ( 96 observed, $67.6 \mathrm{ex}$ pected, SMR 142) in that group. The proportion of smokers in the other groups with similar excesses did not differ markedly from the average within the pulp and paper industry. In addition the proportion of smokers in the general Finnish male population was roughly the same (11, Piha and co-workers, unpublished). Thus the observed excess coronary mortality in these groups could not be explained by differences in smoking habits.

\section{Discussion}

A questionnaire survey proved to be a feasible way to obtain information on smoking habits in an occupational cohort. The response rate in this study of $82.8 \%$ for the total population is close to the rate of $83 \%$ obtained by Dorn (5) from American veterans. Doll \& Hill (4) got a response rate of $69 \%$ from male British doctors. Sillanpää \& Vuori (16), when studying smoking habits and attitudes toward smoking among the staffs of community health centers, obtained a response rate of $88 \%$ to three questionnaires. Rimpelä (15) achieved a response rate of $95 \%$ by means of personal interviews. Rather limited information is available on factors affecting response rates to postal questionnaires on medical matters, but fairly much personal interest in the study is necessary among those questioned.

In a study like the present one, the reliability of the smoking data is crucial. Several factors suggest that we achieved this goal. First, the response rate was fairly high and similar to that of earlier studies. Second, the results were similar to those from other Finnish studies, also for the trend of change. Although several studies have been done in Finland on the smoking habits of the adult population in the whole country or in specified geographic regions, only a few deal with particular occupational groups $(6,8,10,16)$. Poukkula et al (13), in a study of 658 male workers in a Finnish pulp mill in 1967 and 1977, found that the prevalence of smoking was $58 \%$ in 1967 and $45 \%$ in 1977. According to Rimpelä (15) the prevalence of smoking in 1976 was $44 \%$ among Finnish men between 15 and 69 years of age and $23 \%$ among Finnish women of the same age. In 1968 the corresponding figures were 53 and $17 \%$. Karvonen et al (11) studied 525 rural and urban Finnish men in the 20- to 59-year age range. The prevalence of cigarette smoking in that group was $69 \%$ in $1956,14 \%$ greater than that among the male pulp and paper workers of the present study, but the age range 
of the latter was slightly different. Piha and co-workers (unpublished) have studied the smoking habits of the general Finnish population. According to their data, the prevalence of smoking among Finnish men was $35.6 \%$ in 1981 . The percentage of those smoking 1-14 cigarettes a day was 12.4 (including pipe and cigar smokers) and for those smoking more than 14 cigarettes a day was it was 23.2.

The third factor suggesting that the questionnaire data was reliable was the fact that the proportion of smokers in our study was systematically larger among the deceased persons than among the living ones in all but one group (sawmill workers) when the prevalence of smoking in 1956 was compared with the vital status on 31 December 1981.

Close positive correlations between the standardized incidence ratio of lung cancer and the prevalence of smoking or a smoking index have been reported. Pukkala and his co-workers (14) presented a correlation coefficient $(r)$ of 0.96 between the occupational category-specific prevalence of smoking and the corresponding SIR of lung cancer. The correlation coefficient between the smoking index and the SIR of lung cancer was 0.94 . The corresponding correlation coefficients in the present study, 0.12 for the prevalence of smoking in 1981 and 0.14 for the smoking index (figure 1), were low, but it should be noted that the 1981 smoking habits are not the same as those affecting the risk of lung cancer and coronary heart disease. We wanted to calculate the smoking index, however, in order to see whether it would give information in addition to prevalence. In this study it proved not to be useful, but the effect of time cannot be assumed.

There was no correlation between the SIR of lung cancer and the prevalence of smoking in $1956(\mathrm{r}=$ -0.06 , figure 2 ). The correlation between coronary mortality and the prevalence of smoking was also weak $(r=0.34)$. These weak correlations may indicate that there have been factors other than smoking affecting both lung cancer incidence and coronary mortality. However, the smoking habits of the different occupational groups were similar, which makes the determination of a correlation difficult.

According to Axelson (2), smoking habits in various industrial populations rarely diverge so much that the confounding effect of smoking distorts the risk ratios of lung cancer outside the range of $0.5-1.5$. This observation was also true for our data, except for the paper mill group (table 6). The confounding effect of deviating smoking habits is thus not very strong, although clearly noticeable, even when lung cancer is concerned (table 7), as long as the reference population is composed of both smokers and nonsmokers. It is still weaker in the case of coronary mortality because of the relatively smaller effect of smoking on the risk of this disease. Consequently, the observed excesses of lung cancer in some occupational groups, or the observed excesses of coronary mortality, could not be explained by differing smoking habits. Hence occupational factors may be explanators.

The detection of low risks is becoming increasingly important in occupational epidemiology. Thus confounders must be estimated accurately. This study showed that, at least in Finland, the confounding effect of smoking can be evaluated relatively easily by means of questionnaire data. A similar approach may be feasible for most retrospective cohort studies and should be encouraged whenever the risk of smokingassociated illnesses is studied.

\section{Acknowledgments}

This work was supported by the Finnish Work Environment Fund.

We gratefully acknowledge the help given by $\mathrm{Dr} T$ Hakulinen and Mr E Pukkala of the Finnish Cancer Registry, by Dr T Piha of the National Public Health Institute, Department of Epidemiology, and by Ms R-S Koskela of the Institute of Occupational Health in Helsinki. Ms M Matilainen of Enso-Gutzeit Oy provided technical assistance.

\section{References}

1. Asp S. Confounding by variable smoking habits in different occupational groups. Scand J Work Environ Health 10 (1984) 325-326.

2. Axelson $O$. Aspects on confounding in occupational health epidemiology. Scand J Work Environ Health 4 (1978) 85-89. (Letter to the editor).

3. Cochran WG. Sampling techniques. John Wiley \& Sons Inc, New York, NY 1963.

4. Doll R, Hill AB. Mortality in relation to smoking: Ten years' observations of British doctors. Br Med J 1 (1964) 1399-1410, 1460-1467.

5. Dorn HF. Tobacco consumption and mortality from cancer and other diseases. Public Health Rep 74 (1959) 581-593.

6. Hakama M. Lääkärien tupakointitavat [Smoking habits of physicians]. Suom Lääkäril 26 (1971) 1205-1207.

7. Hammond EC, Garfinkel L. Changes in cigarette smoking 1959-1965. Am J Public Health 58 (1968) 30-45.

8. Hirvonen L, Kari-Koskinen $\mathrm{O}$. The smoking habits of male industrial workers. Acta Sociomed Scand 1/3 (1969) 165-172.

9. Jäppinen P. A mortality study of Finnish pulp and paper workers. Br J Ind Med (in press).

10. Kari-Koskinen O, Hirvonen L. Smoking among the female workers of a cotton mill. Acta Sociomed Scand $2 / 1(1970) 23-27$.

11. Karvonen M, Orma E, Keys A, Fidanza F, Brozek J. Cigarette smoking, serum-cholesterol, blood-pressure, and body fatness: Observations in Finland. Lancet 1 (1959) 492-494.

12. Pedersen E, Magnus K, Mork T, Hougen A, Bjelke E, Hakama M, Saxen E. Lung cancer in Finland and Norway: An epidemiological study. Acta Pathol Microbiol Scand (1969): suppl 199.

13. Poukkula A, Huhti E, Mäkäräinen M. Chronic respiratory disease among workers in a pulp mill. Chest 81 (1982) 285-289.

14. Pukkala E, Teppo L, Hakulinen T, Rimpelä M. Occupation and smoking as risk determinants of lung can- 
cer. Int J Epidemiol 12 (1983) 290-296.

15. Rimpelä M. Adult use of tobacco in Finland in the 1950's to 1970's. Department of Public Health Sciences, University of Tampere, Tampere (Finland) 1978. (Publication number M 40/78 (1978)).

16. Sillanpää $\mathbf{M}$, Vuori J. Differences in smoking habits and attitudes toward smoking between medically trained staff and other staff of community health centres. Depart- ment of Public Health, University of Turku, Turku (Finland) 1984. (Publication number M 78 (1984)).

17. Steenland K, Beaumont J, Halperin W. Methods of control for smoking in occupational mortality studies. Scand J Work Environ Health 10 (1984) 143-149.

Received for publication: 11 April 1986 